\title{
LEGAL PROTECTION AGAINST INDONESIAN WORKERS (TKI) IN ABROAD
}

\author{
Yaya Kareng \\ Sripatum University Thailand \\ yahya31490@gmail.com \\ Sri Yulianingsih \\ Sultan Agung Islamic University \\ sriyulianingsih46@gmail.com
}

\begin{abstract}
Protection of migrant workers is all the effort the protection of the interests of prospective workers / migrant workers in realizing the fulfillment of their rights in accordance with the legislation, both before, during, and after work. Protection of migrant workers organized in the International Convention on the Protection of the Rights of All Migrant Workers and Members of Their Families (International Convention on the Protection of the Rights of All Migrant Workers and Members of Their Families) 1990. In addition there are other international conventions. While the protection of migrant workers is regulated in Act No. 39/2004 on the Placement and Protection of Indonesian Workers Abroad, but this law is more concerned with procedural and procedures for the placement of workers abroad, and only slightly regulate the rights and guarantees the protection of the rights of migrant workers and members of their families. Besides the protection of migrant workers by the government based on the country's constitution, as done by the Department of Foreign Affairs (MOFA) RI.
\end{abstract}

Keywords: Foreign Affairs; Law; Migrant Workers; Protection.

\section{A. INTRODUCTION}

Every worker has the right to equal opportunity to choose, obtain, or changed jobs and earn a decent income inside or outside the country. Placement of workers abroad, a national program in an effort to improve the welfare of workers and their families as well as the development of quality human resources. TKI placement is done by utilizing the international labor market through improved quality of labor competencies with optimal protection since before departure, while working abroad to come back in Indonesia ${ }^{1}$.

In performing the duties are many migrant workers involved in the torture case. There are no changes to the various cases before it happens, just past cases of abuse migrant workers is increasing. The government seemed to not learn the mistakes which the occurrence of similar cases before. As if it was an ordinary thing when torture

\footnotetext{
1 http://www.poskota.co.id/berita-

terkini/2011/07/02/200-tki-menanti-hukuman-

mati accessed on March 29, 2019
} 
migrant workers each year. Mentioned already there are regulations governing the protection of migrant workers. But the fact that the same cases still occur and the graphics are not decreased increases. Question about the government's performance in addressing the many that have gone before.

\section{B. DISCUSSION}

\section{Definition of TKI}

Indonesian Workers (TKI abbreviated) is the designation for Indonesian citizens who work abroad in the employment relationship for a given period of time with pay. However, the term migrant workers often connoted with blue-collar workers. Female migrant workers are often called Labor Women (TKW) ${ }^{2}$.

TKI is often referred to as foreign exchange heroes for a year can generate income 60 trillion (2006). On March 9th 2007 operational activities in the field of the Placement and Protection of migrant workers abroad have been transferred to BNP2TKI. Previous all operational activities in the field of the Placement and Protection of Indonesian Workers abroad carried out by the Directorate General of Manpower and Overseas Employment (PPTKLN) Ministry. ${ }^{3}$

Almost all Indonesian migrant workers or migrant workers illegally

2 Shandra Ardiansyah, 2011. "Legal Protection for migrant workers". Press UNY Yogyakarta, accessed on March 29, 2019.

3http://tki-stories.blogspot.com/2009/01/definisi-

tki-wikipedia.html, accessed on March 29, 2019. experienced salary cuts. This piece is mentioned as placement fees and "service charges" claimed by the recruitment agency of the workers it sends. The amount of pieces is varied, ranging from three months to seven, even up to nine months' salary. Not a few migrant workers are forced to submit all his salary and had to work without pay for months. This practice gave rise to the impression that migrant workers are the most actual forms of slavery in Indonesia.

\section{Placement of Migrant Workers in Abroad}

Placement of migrant workers abroad can only be made to a country whose government has made a written agreement with the Government of Indonesia or to a country that has legislation that protects foreign workers. For security reasons, the Government set certain countries closed to the placement of migrant workers, among other destinations in the state of war, natural disasters, or of contracting infectious diseases. Especially for the placement of migrant workers in employment and to particular occupations are regulated separately, for example, work as a sailor4.

Placement prospective migrants / migrant workers abroad is directed at the appropriate positions in accordance with the expertise,

4http://www.bantuanhukum.info/?page $=$ detail\&cat $=$ B09\&sub=B0905\&prod=B090501\&t $=3 \&$ ty $=2$, accessed on March 29, 2019. 
skills, talents, interests, and abilities. Placement prospective migrants / migrant workers carried out with due regard to the dignity, the dignity, human rights, legal protection, equal employment opportunities, and availability of labor with emphasis on national interests. It is forbidden to put prospective migrants / migrant workers in the office and place of employment against human values and moral norms and legislation, both in Indonesia and in the country of destination or the country of destination which has been declared closed.

Implementation of the placement of workers abroad can be done by:

1. Placement By the Government Placement of migrant workers abroad by the government, only on the basis of a written agreement between the Government and the state governments incorporated in the destination country.

2. Placement by the Company Implementing Private Placement of Indonesian Migrant Workers (P3TKIS)

Businesses will be P3TKIS obtain written permission in the form of the company's license Placement of Indonesian Workers (SIPPTKI), after fulfilling the requirements:

a. Limited individual legal entity (PT),

b. Has a paid-up capital which is listed in the certificate of incorporation, at least three billion rupiah,

c. Meyetor money to the bank as collateral in the form of deposits amounting to five hundred million rupiah in state banks,

d. Having a work plan the placement and protection of migrant workers abroad at least for three years running,

e. Having a training unit of work, and

f. Have facilities TKI placement services.

TKI placement on individual users is done through business partners in the country of destination. Business Partner is a legal entity established in accordance with the provisions of the country of destination. For individual users, can employ migrant workers on the job, among others, as Housemaid, babysitter or nurse the elderly man, driver, gardener / garden (informal sector).

Protection for prospective migrant workers were dispatched abroad by P3TKIS includes activities prior to departure (pre-placement), during the placement abroad, and up to the back ground water (after placement). Henceforth, workers who work abroad as individuals entitled to protection of Indonesian Representative.

\section{Death Penalty TKI overseas}

Ministry of Foreign Affairs will remain concerned with the 
protection of about 1.5 million Indonesian migrant workers (TKI) who are currently working in Saudi Arabia. This is done even if Saudi Arabia would impose a moratorium on granting work visas to migrant workers by July 2nd, 2011.

Currently there are 2.1 million migrant workers out of the total 3.4 Indonesian citizens who work abroad. Of whom about 1.5 million are expected to be in Saudi Arabia. Moreover, there are currently negotiations between the Government of Indonesia and Saudi Arabia over the issue of protection of migrant workers. Representatives of the two countries are still discussing the core issues that will be included in the new agreement later ${ }^{5}$.

From the government side wants no clarity regarding the protection of migrant workers. Giving one day off every week, passports held by the workers, and there is a minimum standard salary received by workers. The Indonesian government also wants the inclusion of a clear job description to do migrant workers while in the employer's home. There was also a joint task force between the two countries are responsible for monitoring their implementation.

Meanwhile, Head of the National Agency for Placement and Protection of Migrant Workers (BNP2TKI) said that every case or issues affecting migrant workers

5http://www.bantuanhukum.info/?page = detail\&cat $=$ B09\&sub=B0905\&t=2, accessed on March 29, 2019. abroad, including in Saudi Arabia, the government has always been proactive to defend. No exception for workers who work in Saudi illegally or non-procedural. To minimize the cases faced by migrant workers, especially women migrant workers who work in the household sector, the government is tightening procedures TKI placement6.

Migrant Workers Protection Task Force members of the newly formed presidential promptly went to Saudi Arabia to seek forgiveness for the rescue workers who threatened the death penalty in Saudi Arabia. Migrant workers facing the death penalty in Malaysia and Saudi Arabia estimated 200 people where 70 percent of cases of drug-related homicides by 28 percent and two percent other cases.

Tragic fate of Indonesian Workers (TKI) abroad seemed never ending. Besides beaten and raped, the threat of stoning to death, even the death penalty to haunt them. After Ruyati, there are 200 foreign hunters citizen involved in a variety of cases in several countries, as if waiting for death. They are currently waiting for a helping hand to be free of turn hanged or beheaded.

There are about 5 million citizens who live and work abroad. The actual number of migrant workers from the truly problematic only slightly. They are scattered in a number of countries such as Saudi 
Arabia, China, Singapore and Malaysia. The majority of Indonesian citizens facing the death penalty abroad were freed. There is also obtaining a reduced sentence or a pardon. Because the government continues to fight for them7.

RI representatives in these four countries will escort them through the legal process in court. Based on available data, the number of citizen reached 3,353,631, consisting of 2,029,528 people TKI, professional 269400 people, Ship's Men (ABK) 198461 people, students 660746 people and citizens who are married to foreign nationals 190496 people.

To be Indonesian workers (TKI) is required a management that need to be considered, so as not to be a problem in implementing the tasks become a migrant worker. Many illegal Indonesian workers for not heeding the requirements to become a migrant worker, a compulsory document prospective workers, education and training, employment agreement. Terms of a migrant worker:

a. To be at least 18 (eighteen) years except for prospective workers who will work for individual Users of being at least 21 (twenty-one) years

b. Physically and mentally healthy;

c. Not in a state of pregnancy for women candidates for employment; and

d. Educated at least primary school graduate or equivalent.

prospective workers:

a. National Identity Card, the latest education diploma, birth certificate or certificate of birth recognition;

b. The certificate of marital status for those who are married attaching a copy of a marriage certificate;

c. The certificate of the husband or wife permission, permission of parents or guardian permission;

d. Labor competency certificate;

e. Health certificate based on the results of medical examination and psychological;

f. Passports issued by the local Immigration Office;

g. Work visa;

h. Employment agreement;

i. The employment agreement, and

j. KTKLN (Card Overseas Employment) is an identity card for workers who meet the requirements and procedures for work abroad.

Education and training:

a. Prospective migrants must have a certificate of competence in accordance with the terms of office work.

b. In the case of migrant workers has not had work competence in executing private placement workers are obliged to education and training in accordance with the work to be done. 
Education and vocational training for potential migrant workers for the purpose of:

a. preparing, placing and develop job competence prospective migrants;

b. provide knowledge and understanding of the situation, customs, culture, religion, and risks of working abroad;

c. provide the ability to communicate in discussing the country of destination; and

d. provide knowledge and understanding of the rights and obligations of prospective migrants / migrant workers.

Employment agreement:

The working relationship between the User and TKI occur after work agreement agreed upon and signed by the parties.

Every worker shall sign the agreement concerned prior TKI departure abroad.

The employment agreement was signed in the presence of officials responsible agencies in the field of employment.

\section{Protection of Migrant Workers in Abroad}

Protection of migrant workers is all the effort the protection of the interests of prospective workers / migrant workers in realizing the fulfillment of their rights in accordance with the legislation, both before, during, and after work.

Protection of migrant workers organized in the International
Convention on the Protection of the Rights of All Migrant Workers and Members of Their Families (International Convention on the Protection of the Rights of All Migrant Workers and Members of Their Families) 1990. In addition there are other international conventions. While the protection of migrant workers is regulated in Act No. 39/2004 on the Placement and Protection of Indonesian Workers Abroad, but this law is more concerned with procedural and procedures for the placement of workers abroad, and only slightly regulate the rights and guarantees the protection of the rights of migrant workers and members of their families. Besides the protection of migrant workers by the government based on the country's constitution, as done by the Department of Foreign Affairs (MOFA) RI ${ }^{8}$.

1. Based on the Protection of Migrant Workers Convention 1990

Migrant workers according to the convention is the person who will be, or has been doing a paid job in a country of which he is not a citizen. It recognizes and provides protection against the basic rights of migrant workers that apply to all migrant workers (who documented or not) and their family members and non-discrimination. 8http://kelanakota.suarasurabaya.net/?id=54d143d 5c5837519f799312c04728b25201194493, accessed on March 29, 2019. 
2. Protection of Indonesian Citizens and Legal Entities Indonesia. It becomes part of the work program and the responsibility of the Ministry of Foreign Affairs (MOFA) RI. Protection of migrant workers through:

a. The political approach, perform and make a cooperation agreement between the government of the recipient country migrant workers, fellow labor-sending countries,

b. The provision of humanitarian aid, it is more given to workers who were put on trial in the local country for allegedly committing a crime. This protection is done by visiting periodically, monitoring and providing moral support to him. It also meets the basic needs of daily during the judicial process, provide clergy and health / psychosocial, as well as assisting the return to the homeland;

Legal aid (assistance; legal consultations, to act as a mediator in resolving labor disputes between migrant workers with the user; providing an advocate).

c. Protection of migrant workers based on the Universal Declaration of Human Rights.
Human rights need to be protected by the rule of law so that people will not be forced to choose as a last attempt to revolt against oppression, the development of friendly relations between the countries should be encouraged.

In addition, in Article 5, Universal Declaration of Human Rights states that:

"No one shall be subjected to torture or cruel, obtain treatment or punishment is inhuman or demeaned her dignity."

In Article 6 Universal Declaration of Human Rights states that:

"Everyone has the right to recognition as a person before the law wherever he is."

Article 7 Universal Declaration of Human Rights states that:

"Everyone is equal before the law and entitled to equal protection of the law without discrimination. All are entitled to equal protection against any form of discrimination which is contrary to this Declaration and against any incitement to such discrimination. "

In Article 8 Universal Declaration of Human Rights states that: 
"Everyone is entitled to effective assistance of competent national tribunals for acts violation the fundamental rights granted him by the constitution or by law."

In Article 9 Universal Declaration of Human Rights states that:

"No one may be arrested, detained or disposed of arbitrarily."

In Article 13 of the Universal Declaration of Human Rights states that:

"Everyone has the right to freedom of movement and dwell within the borders of each state."

Everyone has the right to leave a country, including his own, and to return to his country. "

d. Protection of migrant workers Under Act No. 39 of 2004

Meanwhile, if we look to in Article 5 of Act No. 39 of 2004 states that:

a. The government is set up, develop, implement, and oversee the implementation of the placement and protection of migrant workers abroad.

b. In carrying out the tasks referred to in paragraph (1), as a Government may delegate authority and / or assistant task to local authorities in accordance with statutory regulations.

In Article 6 of Act No. 39 of 2004 states that:

"The government has a responsibility to increase efforts to protect migrant workers abroad."

In Article 7 of Act No. 39 of 2004 states that:

In carrying out the duties and responsibilities referred to in Article 5 and Article 6 Government must:

a. Guaranteeing the rights of prospective migrants / migrant workers, both concerned depart through the implementing of migrant workers, as well as those set out independently;

b. Oversee the implementation of the placement of prospective migrants;

c. Establish and develop information systems placement of prospective workers abroad;

d. Diplomatic efforts to ensure the fulfillment of the rights and protection of migrant workers optimally in the country of destination; and 
e. Provide protection to migrant workers during the earlier times of departure, time placement, and full-time placement.

\section{CONCLUTION}

Placement of migrant workers abroad can only be made to a country whose government has made a written agreement with the Government of Indonesia or to a country that has legislation that protects foreign workers. For security reasons, the Government set certain countries closed to the placement of migrant workers, among other destinations in the state of war, natural disasters, or of contracting infectious diseases. Especially for the placement of migrant workers in employment and to particular occupations are regulated separately, for example, work as a sailor.

Fundamental rights are attached to the induvidual strictly protected under the law, so that the problems of migrant workers abroad persecution is happening, basically very contrary to what is laid out in the Universal Declaration of Human Rights. And the government must act decisively on issues of increasing the dissolved-out is to uphold and promote human rights of Indonesia in the eyes of the world.

The government has issued legislation to ensure the protection of migrant workers, such as Law 13/2003 on Labor, who then encourages the enforcement of Act No. 39/2004 on the Placement and Protection of Indonesian Migrant Workers Abroad (Law of PPTKILN) has been trying to facilitate "the interests of" migrant workers in general. 


\section{BIBLIOGRAPHY}

\section{Books:}

Shandra Ardiansyah, 2011. "Legal Protection for migrant workers". Press UNY Yogyakarta, accessed on March 29, 2019.

\section{Internet:}

http://www.poskota.co.id/berita-terkini/2011/07/02/200-tki-menanti-hukuman-mati accessed on March 29, 2019

http://tki-stories.blogspot.com/2009/01/definisi-tki-wikipedia.html, accessed on March 29, 2019.

http://www.bantuanhukum.info/?page=detail\&cat=B09\&sub=B0905\&prod=B090501\&t=3\&ty $=2$, accessed on March 29, 2019.

http://www.bantuanhukum.info/?page=detail\&cat=B09\&sub=B0905\&t=2, accessed on March 29, 2019.

http://www.suarakarya-online.com/news.html?id=282041, accessed on March 29, 2019. http://kelanakota.suarasurabaya.net/?id=54d143d5c5837519f799312c04728b25201194493, accessed on March 29, 2019. 